\title{
Apoptosis Induction of Newcastle Disease Virus Strains (AF 2240 \& V4-UPM) on HT-29 Human Colorectal Adenocarcinoma Cells
}

\author{
Rowa M. Assayaghi ${ }^{1, *}$, Aied M. Alabsi ${ }^{2}$ and Abdul Manaf Ali ${ }^{1}$ \\ ${ }^{1}$ Department of Biotechnology, Faculty of Bioresources and Food Industry, University Sultan Zainal Abdin, Tereng- \\ ganu, Malaysia.
}

${ }^{2}$ Department of Oral and Craniofacial Science, Faculty of Dentistry, University of Malaya, Kuala Lumpor, Malaysia. ${ }^{*}$ Corresponding author: Rowa M. Assayaghi, Department of Biotechnology, Faculty of Bioresources and Food Industry, University Sultan Zainal Abdin, Terengganu, Malaysia, E-mail: rowamohammed2010@yahoo.com

Received Date: June 27, 2016; Accepted Date: September 04, 2016; Published Date: September 07, 2016

Citation: Rowa M. Assayaghi, et al. (2016) Apoptosis Induction of Newcastle Disease Virus Strains (AF 2240 \& V4-UPM) on HT-29 Human Colorectal Adenocarcinoma Cells. 4: 1-8.

\begin{abstract}
Newcastle disease virus (NDV) is a negative-sense single stranded RNA virus of the Paramyxoviridae family that causes severe disease in several avian species. NDV has been shown to possess oncolytic properties and in the current study, the effect of NDV strains AF 2240 and V4-UPM on the HT-29 human colorectal adenocarcinoma cells was observed. The cytolytic effects of the virus strains were determined by using MTT assay. The CD50 value for cytolytic effects of NDV strains AF 2240 and V4-UPM on HT-29 after 72h was 16 and $33 \mathrm{HAU} \mathrm{mL} \mathrm{m}^{-1}$, respectively. No cytolytic effect was observed on 3T3 normal mouse fibroblast cells when treated with CD50 dose of both NDVstrains. HT-29 cells were analyzed by using AO/PI staining method and observed that NDV treatment with both strains induced a time-dependent increasing in apoptosis of treated cells compared to non-treated HT-29 cells. Analysis of caspases 3, 8 and 9 the key executioners in apoptosis has shown that both 3 and 9 caspases were significantly increased in HT-29 after treatment with both NDVstrains. The effects of both strains of NDV on the expression level of apoptosis-associated proteins revealed an increased in Bax and decreased in Bcl-2 protein levels. The results suggest that NDV strains AF 2240 and V4-UPM induced apoptosis on HT-29 cells.
\end{abstract}

Keywords: NDV; AF 2240; V4-UPM; Apoptosis; HT-29; Bcl-2

\section{Introduction}

An oncolytic virus is the virus that has an ability to replicate in tumor tissue and destroys it without causing damage to non-tumor tissues. Many reasons such as the nature of delivery, infection, and replication of oncolytic viruses make oncolytic virotherapy extremely useful for treating cancer patients. Oncolytic virotherapy targets cancer cells to achieve a strong cytolytic effect $[1,2]$. Newcastle disease virus (NDV) is a member of the genus Avulavirus in the family Paramyxoviridae. The genome of NDV is a non-segmented, singlestranded, negative- sense RNA of 15,186 nucleotides [3-5]. NDV is classified as a virus with inherent oncolytic properties which anti-cancer effect was first reported by Cassel and Garret in 1965. Since then NDV has been investigated for its anti-cancer effects and scientists are interested in NDV because it can replicate up to 10000 times better in human neoplastically transformed cells than in most normal human cells [6-9]. Numerous reports had shown that the virus cannot replicate in non-transformed cells, such as fibroblast cells, resting $\mathrm{T}$ lymphocytes, and normal primary culture. Besides,

(C)2016 The Authors. Published by the JScholar under the terms of the Creative Commons Attribution License http://creativecommons.org/licenses/by/3.0/, which permits unrestricted use, provided the original author and source are credited.
NDV is an immunostimulatory agent, as it can induce antitumor activities of a variety of effector cells, including NK cells, macrophages, and CTL $[7,10,11,12]$. NDV strain AF 2240, is a Malaysian neurotropic-viscerotropic velogenic strain which is often used as the challenge virus in vaccine trials. It is known as a very virulent strain, heat stable, viscerotropic. AF 2240 was first isolated in the 1960s from a local field outbreak and was reported to cause high mortality and morbidity in the poultry in Malaysia [13-15]. NDV strain V4 is an avirulent strain and also known as Queensland strain. The strain is indicated to be immunogenic and highly transmissible. Even though all strains of NDV had thermostable hemagglutinins, only four strains, which include V4, were relatively heat-resistant. Owing to this feature, V4 virus was developed as a thermostable feed pellet vaccine by Universiti Putra Malaysia researchers which then known as V4-UPM [16,17].

Both NDV strains AF 2240 and V4-UPM have antineoplastic properties and are currently being tested as anticancer agents in various cancerous cells in vivo and in vitro in Malaysia such as breast cancer cell lines (MCF-7 and MDA-231), brain tumor cell lines (DBTRG.5MG and U87MG) and leukemia cell lines (HL-60 and CEM-SS) [18-22]. This study was to determine how NDV strains (AF 2240 and V4-UPM) induce cell death on 
HT-29 human colorectal adenocarcinoma cells via investigations on morphological changes and apoptotic gene expression.

\section{Materials and Method}

\section{HT-29 cells culture:}

Human colorectal adenocarcinoma (HT-29) cells and mouse fibroblast (3T3) cells were purchased from American Type Culture Collection (ATCC). HT-29 and 3T3 cells were cultured in RPMI-1640 (Sigma, USA) containing 10\% fetal bovine serum (FBS), $100 \mathrm{U} / \mathrm{mL}$ penicillin and $100 \mu \mathrm{g} / \mathrm{mL}$ streptomycin at 37 ${ }^{\circ} \mathrm{C}$ in a humidified atmosphere of $5 \% \mathrm{CO} 2$ in air. The cells were grown to a semi-confluence state and sub-cultured at three to four days interval.

\section{Propagation and purification of NDV strains AF 2240 and V4-UPM:}

NDV strains stocks were propagated in allantoic fluids of 9-11 days-old embryonated chicken eggs at $37^{\circ} \mathrm{C}$. After four days of incubation, the eggs were chilled at $4^{\circ} \mathrm{C}$ for $24 \mathrm{~h}$. Thereafter, allantoic fluids were aseptically harvested and purified as previously described [23,24]. The virus titer was determined by a hemagglutination test with freshly prepared young chicken red blood cell [25].

\section{MTT Cytotoxicity assay:}

The cytolytic effects of NDV strains AF 2240 and V4-UPM on HT-29 and 3T3 cells were measured using Microtitration (MTT) cytotoxicity assay [26] 3T3 cell lines were used as control. HT-29 and 3T3 cells were seeded in 96-well plate (Nunclon $^{\text {rx }}$, Denmark) at a density of $5 \times 10^{5}$ cells/ well and incubated for $24 \mathrm{~h}$ to facilitate attachment. Thereafter, the medium was discarded and $200 \mu \mathrm{L}$ of treatment medium containing virus suspension and 2-folded virus dilution were added into the wells. Wells containing only Phosphate Buffer Saline (PBS) served as control. Following $72 \mathrm{~h}$ incubation, $20 \mu \mathrm{L}$ of MTT solution $(5 \mathrm{mg} / \mathrm{mL})$ was added to each well then the plate was further incubated for $4 \mathrm{~h}$. The medium was removed and $100-150 \mu \mathrm{L}$ of dimethyl sulfoxide (DMSO) was added into the wells to soluble the crystals. Finally, the optical density (OD) was measured by ELISA reader (Tecan Infinite M200, Switzerland) at wavelength of $570 \mathrm{~nm}$. Then graphs of percentage of viable cells versus virus titer HAU (hemagglutination unit) were plotted. The value of CD50 was determined from the graphs obtained at the concentration that cause $50 \%$ cell reduction as compared with controls.

\section{Observation HT-29 cells by phase contrast light microscope:}

HT-29 cells were treated with NDV CD50 for $24 \mathrm{~h}, 48 \mathrm{~h}$ and $72 \mathrm{~h}$, respectively. After incubation periods, cell morphology was observed under inverted phase contrast microscope (Nikon TS100, Japan) to determine morphological changes.

\section{Fluorescence staining:}

HT-29 cells were cultured in six-well plate at a density of $4 \times$ $10^{4}$ cells/well with NDV CD50 for $24 \mathrm{~h}, 48 \mathrm{~h}$ and $72 \mathrm{~h}$ for both virus strains. The morphological changes and the proportions of apoptotic, necrotic and normal viable cells were observed. Cells were stained using propidium iodide (PI) and acridine orange $(\mathrm{AO})$ double staining according to standard procedure [27]. After the incubation period, the cells were washed with PBS, $\mathrm{pH} 7$ and then incubated with $5 \mu \mathrm{L}$ of $\mathrm{AO}(10 \mu \mathrm{g} / \mathrm{mL})$ and $5 \mu \mathrm{L}$ of PI $(10 \mu \mathrm{g} / \mathrm{mL})$ at a ratio of $1: 1$ in $1 \mathrm{~mL}$ of cells. Cells were centrifuged at $1000 \mathrm{rpm} / 5 \mathrm{~min}$ and $10 \mu \mathrm{L}$ of suspension was pippetted on slide before putting on cover slip. Within $30 \mathrm{~min}$, the slide was analyzed using fluorescent microscope (Nikon TE2000-U, Japan) and then viable, apoptotic and necrotic cells were scored as described [27].

\section{Analysis of caspase-3/7, 8 and 9 activities:}

Caspase-3/7, 8 and 9 activities were measured using CaspaseGlo ${ }^{\varpi}$ 3/7, 8 and 9 Assay Kit (Promega,USA). HT-29 cells were grown in white-wall, optical bottom 96-well plate and treated with NDV at CD50 for $3 \mathrm{~h}, 6 \mathrm{~h}$ and $24 \mathrm{~h}$. In blank wells, $100 \mu \mathrm{L}$ of complete RPMI-1640 medium and $100 \mu \mathrm{L}$ of Caspase-Glo ${ }^{\circ}$ reagent were added. After the incubation time, $100 \mu \mathrm{L}$ of the substrate reagent were added to the cells and further incubated for $1 \mathrm{~h}$ at room temperature. The contents were mixed using a plate shaker; at 300 to $500 \mathrm{rpm}$ for about 30s. Finally, luminescene intensity was measured by using Luminescene plate reader (Tecan Infinite M200, Switzerland).

Reverse transcription polymerase chain reaction (RT-PCR) of some apoptotic genes (Bax \& Bcl-2) on HT-29 cells:

HT-29 cells at a density of $1 \times 10^{6}$ cells/wells were treated with NDV CD50 for $24 \mathrm{~h}, 48 \mathrm{~h}$ and $72 \mathrm{~h}$. Total RNA was isolated from the treated cells with innuPREP RNA extraction kit (analytikjena, Germany) and reversely transcribed into cDNA with human specific primers for Bax, B-cell lymphoma $2(\mathrm{Bcl}-2)$ and $\beta$-actin. Primers sequences were as follows: (a) $\beta$-actin, Sense: 5'-GTGGACATCCGCAAAGAC-3' and Antisense: 5'-TCAACGCAATGTGGGAAG-3'; (b) Bax, Sense: 5'-CCAGCTGCCTTGGACTGT-3' and Antisense: 5'-ACCCCCTCAAGACCACTCTT-3' and (c) Bcl-2 Sense: 5'-GGCAATGTGACTTTTTCCAA-3' and Antisense: 5'-GGCTGATATTCTGCAACACTG-3' [28]. Briefly, 35 cycles of PCR amplification, were performed at $95^{\circ} \mathrm{C}$ for $3 \mathrm{~min}$ for initial denaturation, $95^{\circ} \mathrm{C}$ for $35 \mathrm{~s}$ for second denaturation, annealing at $61^{\circ} \mathrm{C}(\mathrm{Bax})$ and $58^{\circ} \mathrm{C}(\mathrm{Bcl}-2$ and $\beta$-actin) for $45 \mathrm{~s}$ then first extension at $72^{\circ} \mathrm{C}$ for $1 \mathrm{~min}$ and final extension at $72^{\circ} \mathrm{C}$ for $5 \mathrm{~min}$ in a $25 \mu \mathrm{L}$ reaction mix. PCR products were separated by $1.5 \mathrm{~g} / \mathrm{L}$ agarose gel electrophoresis and visualized by UV transillumination after ethidium bromide staining. mRNA expression of genes was assessed by correcting housekeeping gene $\beta$-actin, which served as an internal control.

\section{Statistical analysis}

All statistical analyses were performed with IBM SPSS 20 statistical package for Microsoft Windows. The statistical significance of the data has been determined using one-way and two-way analysis of variance (ANOVA). Data were expressed as mean \pm SE for all measurements, $P \leq 0.05$ was considered statistically significant.

\section{Results}

The CD50 value for cytolytic effect of NDV strain AF 2240 on

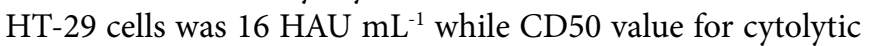
effect of NDV strain V4-UPM on HT-29 cells was 33 HAU $\mathrm{mL}^{-1}$ (Figure 1). While, the same titer of virus strains did not give significant cytolytic effect on 3T3 cells (Figure 2). 


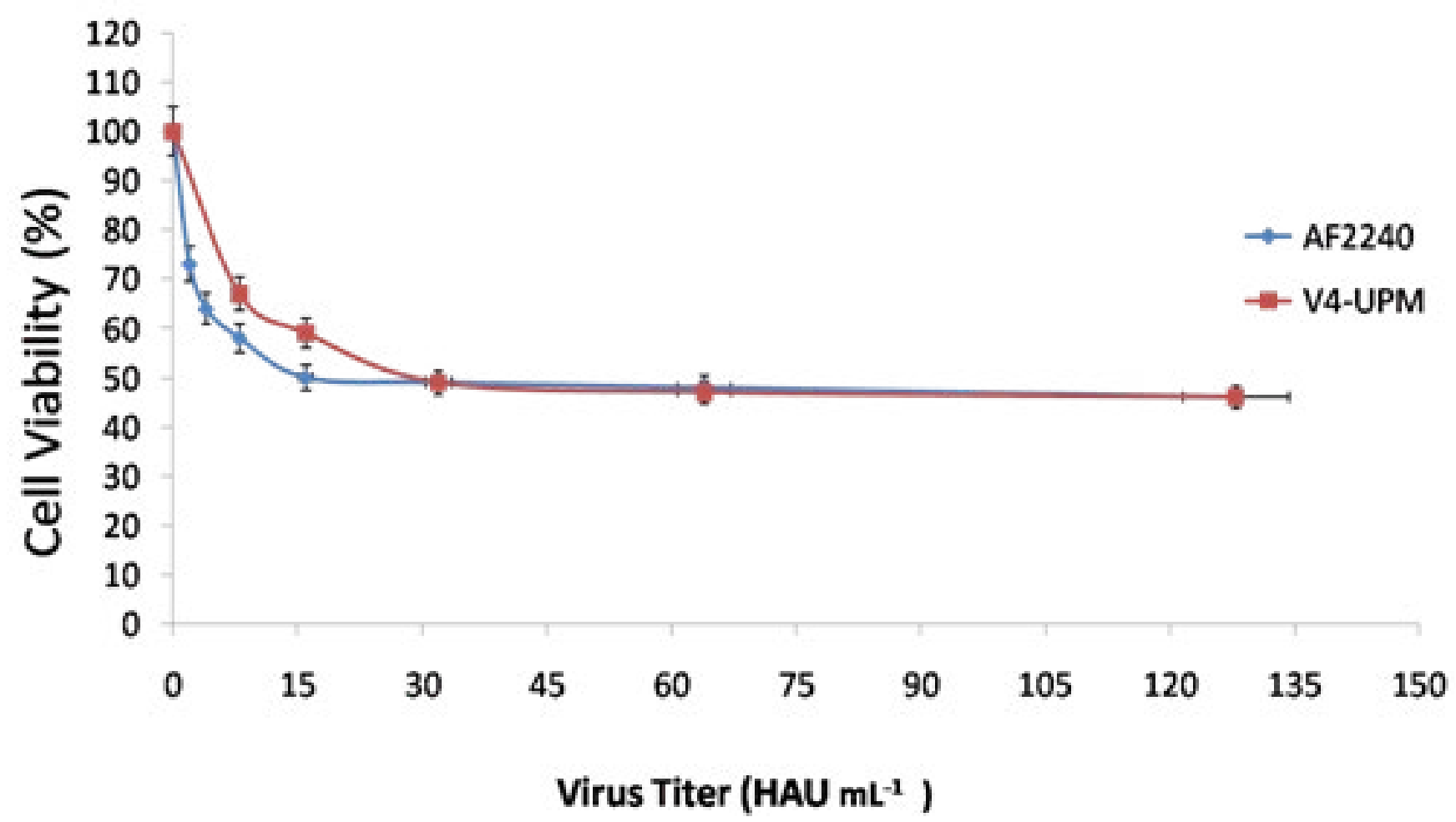

Figure 1: Cytolytic effects of NDV strains AF 2240 and V4-UPM on HT-29 cells. Fifty percent of cell viability (CD50) was obtained at virus titer of $16 \mathrm{HAU} \mathrm{mL}^{-1}$ and $33 \mathrm{HAU} \mathrm{mL}^{-1}$ of AF 220 and V4-UPM, respectively.

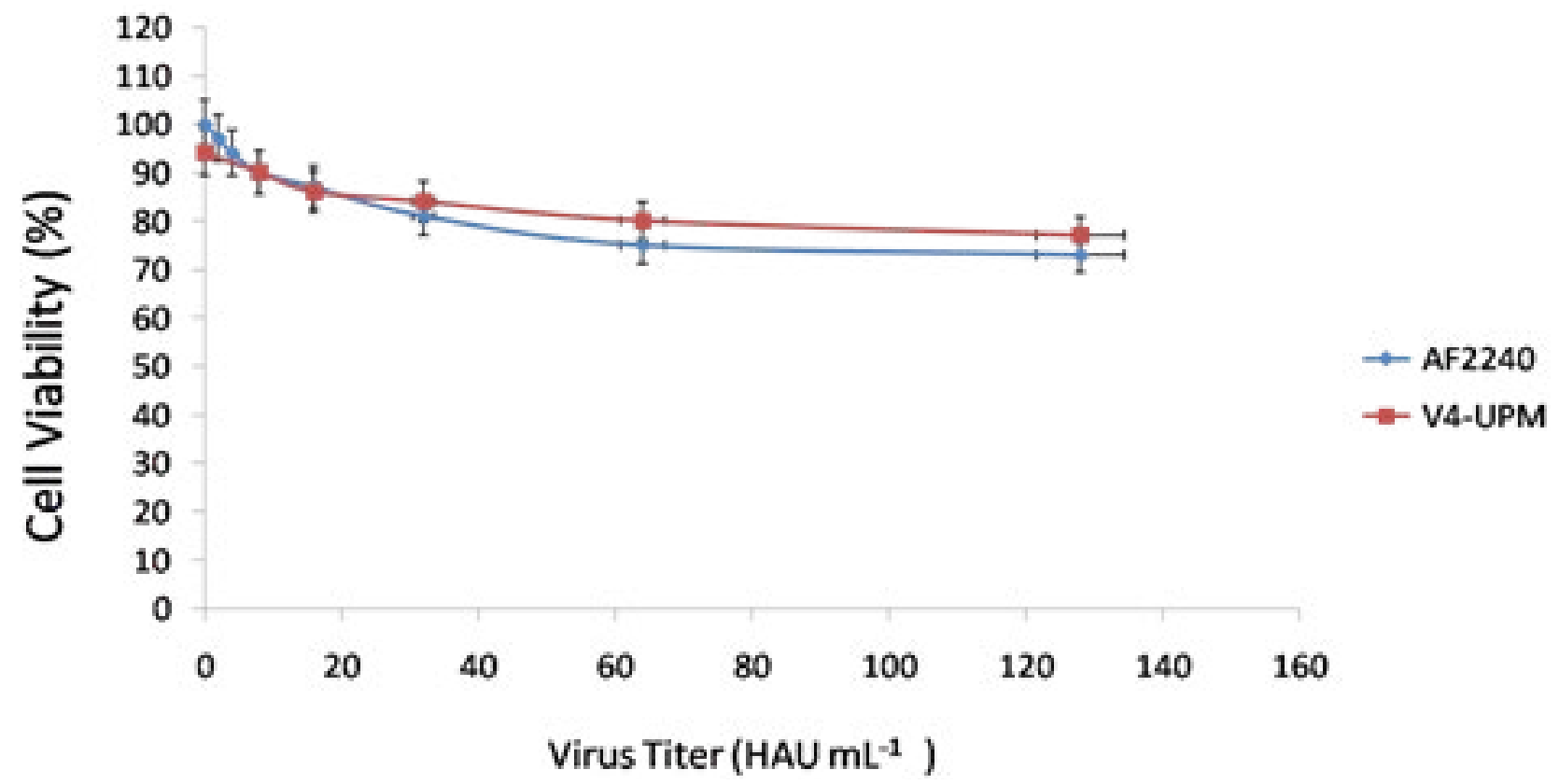

Figure 2: Cytolytic effects of NDV AF 2240 and V4-UPM on 3T3 cells. Fifty percent of cell viability (CD50) was not obtained because the cell reduction was not affected by same virus titer.

HT-29 cells were treated with CD50 of NDV strains (AF 2240 and V4-UPM) at the exposure time $24 \mathrm{~h}, 48 \mathrm{~h}$ and $72 \mathrm{~h}$. The phase contrast and fluorescent microscopes were used to detect the morphological changes and the proportions of apoptotic, necrotic and viable cells in the population of HT-29 cells exposed to NDV strains AF 2240 and V4-UPM at CD50 for $24 \mathrm{~h}, 48 \mathrm{~h}$ and $72 \mathrm{~h}$ compared to untreated HT-29 cells. Under the phase contrast microscope, HT-29 cells were observed as round, atrophic and poorly adherent and floating cells that increased with increasing time exposure. Besides, NDV strains caused shrinkage of the cells and formation of apoptotic bodies (Figure 3D,E,F). Moreover, fluorescent microscopy using acridine orange $(\mathrm{AO})$ and propidium iodide (PI) was carried out; selective permeability property of intact plasma membrane of viable cells allowed the acridine orange to enter the cell and was impermeable to the propidium iodide. The nucleus of viable cells were stained with green when observed under fluorescence microscope whereas the plasma membrane of necrotic cells was no longer intact which allowed propodium iodide to enter and make the cells appear red [27].The necrotic cells can be differentiated from apoptotic cells based on morphological differences which cell blebbing was observed in apoptotic cells (Figure 4B,C) while necrotic cells showed smaller in size and fluoresced orange in color (Figure 4D). 


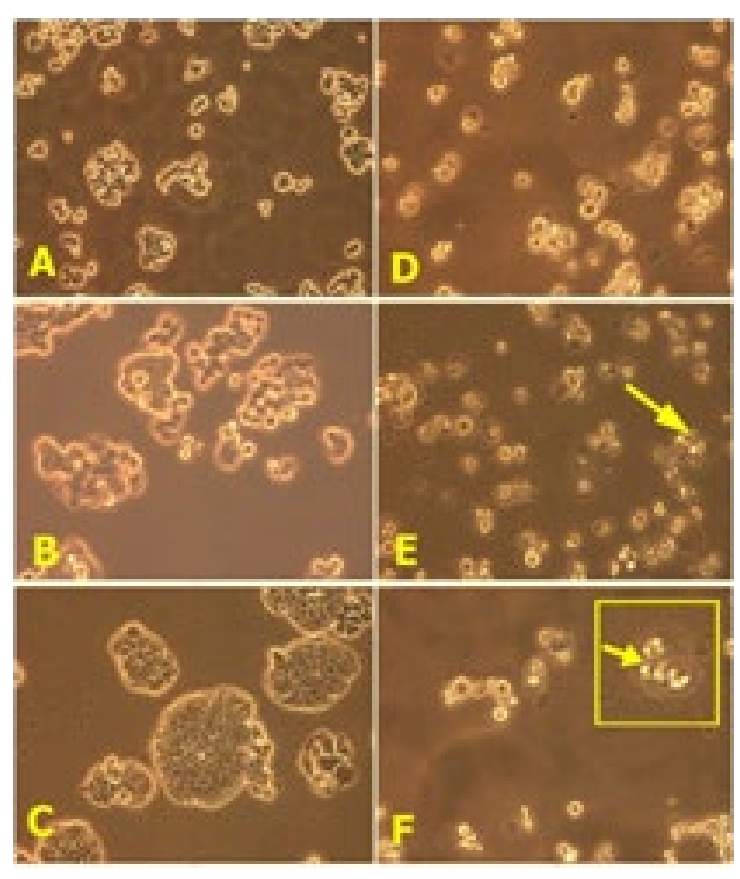

Figure 3: Microscopic examination by phase contrast microscope of HT-29 cells treated with NDV strains AF 2240 and V4-UPM at CD50 titer at $24 \mathrm{~h}, 48 \mathrm{~h}$ and $72 \mathrm{~h}$. (A,B,C) Control (un-treated) cells at $24 \mathrm{~h}$, $48 \mathrm{~h}$, and $72 \mathrm{~h}$ showed normal distribution and morphology. (D,E,F) HT-29 cells treated with CD50 of NDV strains (AF 2240 and V4UPM) at $24 \mathrm{~h}, 48 \mathrm{~h}$, and $72 \mathrm{~h}$. Cells became round, atrophic and poorly adherent and floating cells. Formation of apoptotic bodies were observed (arrows) (200x magnification).

The proportion of viable HT-29 cells treated with NDV strain AF 2240 significantly decreased from $70 \%$ at $24 \mathrm{~h}$ to $59 \%$ at $48 \mathrm{~h}$ and $46 \%$ at $72 \mathrm{~h}(P \leq 0.05)$. While the percentage of apoptotic cells had significantly increased from $19 \%$ at $24 \mathrm{~h}$ to $24 \%$ and $30 \%$ at $48 \mathrm{~h}$ and $72 \mathrm{~h}$, respectively $(P \leq 0.05)$. The necrotic cells were $11 \%$ at $24 \mathrm{~h}$ and significantly increased to $17 \%$ and $24 \%$ at $48 \mathrm{~h}$ and $72 \mathrm{~h}$; respectively $(P \leq 0.05)$ (Figure $5 \mathrm{~A})$.

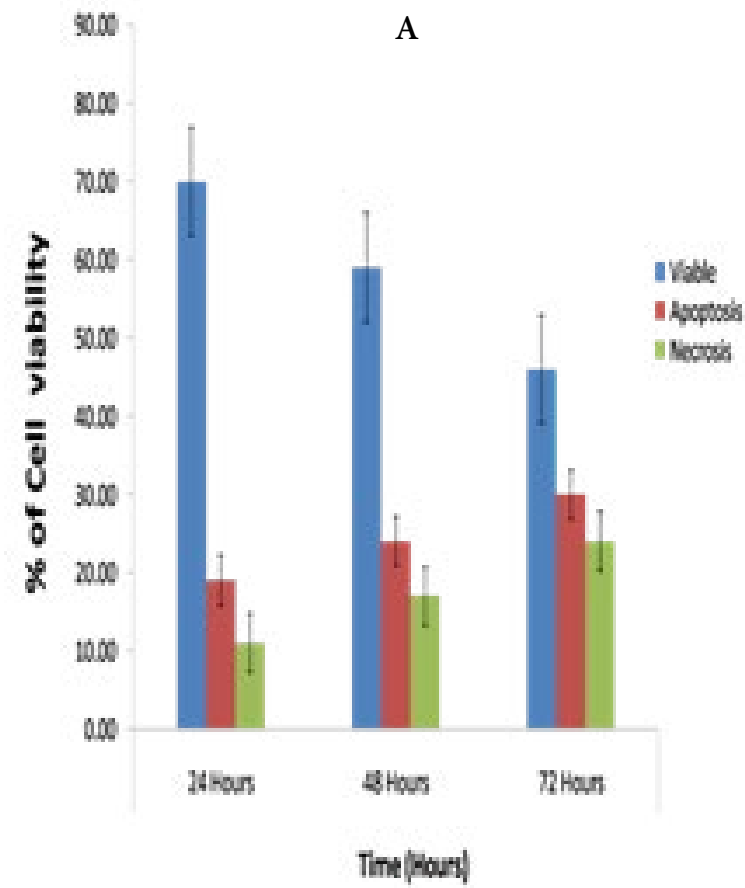

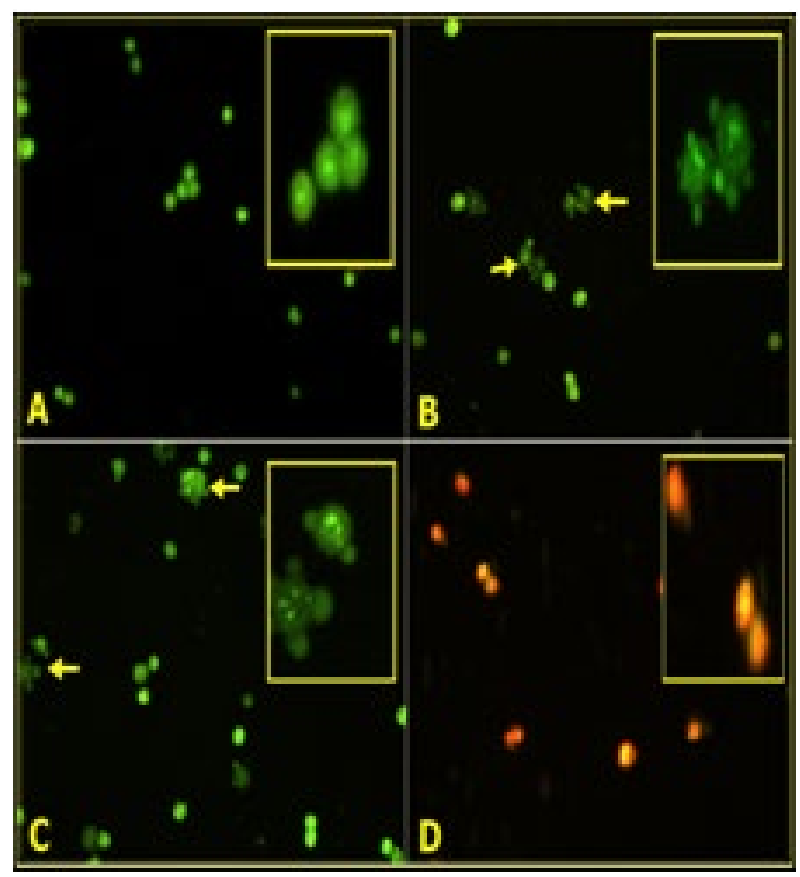

Figure 4: Fluorescence microscopy examination of HT-29 cells treated with NDV strains AF 2240 and V4-UPM at CD50 titer after $72 \mathrm{~h}$ staining with acridine orange and propidium iodide. (A) HT-29 control (un-treated) cells, (B) HT-29 apoptotic cells treated with CD50 16 HAU of NDV AF 2240, (C) HT-29 apoptotic cells treated with CD50 33 HAU of NDV V4-UPM. (D) Necrotic cells. In B \& C cell blebbing were observed (arrows) (200 x magnification).

The percentage of viable HT-29 cells treated with NDV strain V4-UPM significantly decreased from $69 \%, 54 \%$ and $38 \%$ at $24 \mathrm{~h}, 48 \mathrm{~h}$ and $72 \mathrm{~h}$, respectively $(P \leq 0.05)$. On the other hand, percentage of apoptotic cells significantly increased $(P \leq 0.05)$ from $20 \%$ at $24 \mathrm{~h}$ to $26 \%$ at $48 \mathrm{~h}$ and rise continuously to $34 \%$ at $72 \mathrm{~h}$. In contrast, the percentage of necrotic cells was $11 \%$ at $24 \mathrm{~h}$ and significantly increased to $20 \%$ and $28 \%$ at $48 \mathrm{~h}$ and $72 \mathrm{~h}$, respectively $(P \leq 0.05)$ (Figure $5 \mathrm{~B}$ ).

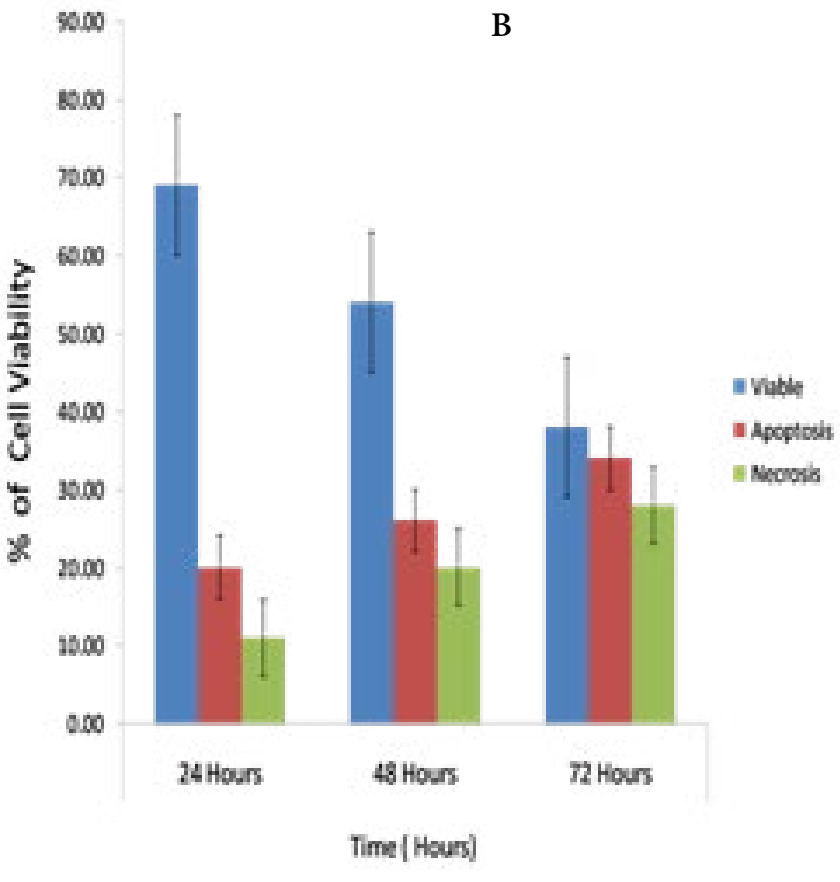

Figure 5: Percentage of viable, apoptotic and necrotic HT-29 cells after treatment with CD50 of NDV strains (A) AF 2240 (B) V4-UPM at different times. 
Caspase-3/7, Caspase- 8 and Caspase- 9 in response to the treatment of NDV AF 2240 and V4-UPM were determined. HT-29 cells exposed to NDV strains AF 2240 at CD50 for 3h, $6 \mathrm{~h}$ and $24 \mathrm{~h}$ compared to untreated HT-29 cells. The activity rate of caspase increasing level was obtained by divided the protein level of caspase at $6 \mathrm{~h}$ by protein level of caspase at $24 \mathrm{~h}$ $(6 \mathrm{~h} / 24 \mathrm{~h})$. Caspase-3/7 protein level was significantly increased $(P \leq 0.05)$, the rate of increase of caspase-3/7 protein level from $6 \mathrm{~h}$ to $24 \mathrm{~h}$ was 1:4 of HT-29 cells treated with NDV AF 2240. While the rate of increase of caspase- $3 / 7$ protein level from $6 \mathrm{~h}$ to $24 \mathrm{~h}$ was only 1:2 of HT-29 cells treated with NDV V4-UPM (Table 1). Moreover, caspase- 8 protein level was significantly increased $(P \leq 0.05)$ and the rate of increase of caspase- 8 protein level from $6 \mathrm{~h}$ to $24 \mathrm{~h}$ was $1: 4$ of HT-29 cells treated with both NDV strains (Table 1). Caspase-9 protein level was also determined and showed significantly increased $(P \leq 0.05)$ and the rate of increase from $6 \mathrm{~h}$ to $24 \mathrm{~h}$ was 1:9 of HT-29 cells treated with NDV AF 2240. While the rate of increase of caspase-9 protein level from $6 \mathrm{~h}$ to $24 \mathrm{~h}$ was $1: 5$ of HT-29 cells treated with NDV V4-UPM (Table 1).

HT-29 cells were treated with CD50 of NDV strains (AF 2240 and V4-UPM) for $24 \mathrm{~h}, 48 \mathrm{~h}$ and $72 \mathrm{~h}$, then mRNA expression of Bax and Bcl-2 genes were observed. The expression of Bax was up- regulated in treated cells while down-regulated in control (non- treated) cells. In contrast, the expression of Bcl2 was up- regulated in control (non- treated) cells while downregulated was found in treated cells. $\beta$-actin which served as an internal control was expressed in all samples at equal level (Figure 6).

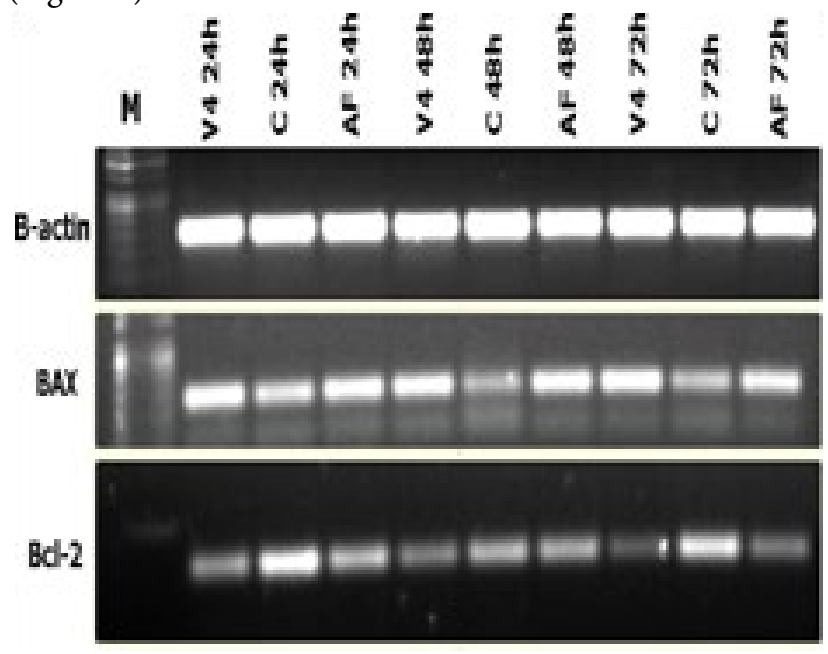

Figure 6: Expression of apoptosis-related genes (BAX and BCL-2) in HT-29 cells treated with NDV strains AF 2240 and V4-UPM at CD50 titer at $24 \mathrm{~h}, 48 \mathrm{~h}$ and $72 \mathrm{~h}$. Repersentive bands of mRNA transcripts separated on a $1.5 \%$ agarose gel after RT-PCR were shown. $\beta$-actin served as an internal control.

M: Marker;V4 24h: HT-29 cells treated with NDV strain V4-UPM for 24h; C 24h: control HT-29 (non-treated) cells at 24h;AF 24h: HT29 cells treated with NDV strain AF 2240 for 24h;V4 48h: HT-29 cells treated with NDV strain V4-UPM for 48h;C 48h: HT-29 control (non-treated) cells at 48h;AF 48h: HT-29 cells treated with NDV strain AF 2240 for 48h;V4 72h: HT-29 cells treated with NDV strain V4-UPM for 72h;C 72h: HT-29 control (non-treated) cells at 72h;AF 72h:HT-29 cells treated withNDV strain AF 2240 for $72 \mathrm{~h}$.

\section{Discussion}

The clinical evaluation of NDV over several decades as anticancer reagent in various clinical settings corroborates its safety and effectively. This is based on its tumor selective replication and oncolytic activities, allowing the virus to selectively attack tumor cells while leaving healthy cells undamaged. Another aspect that has received increasing interest is the ability of NDV to activate host anti-tumor immunity [29]. NDV has been used on several different human tumor cell lines and tumor models world-wide [14]. In this study, Malaysian local strains of NDV, AF 2240 and V4-UPM, were used as oncolytic agents against the HT-29 cell lines. The treatment with both NDV strains resulted in cytolytic effects on the HT-29 cells but not on normal mouse fibroblast (3T3) cells. These results confirmed the effectiveness of NDV as a potent oncolytic agent against cancer cells with almost no effects to normal cells. This characteristic plays an important role and can be considered as one of the primary criteria of anticancer agents. Therefore, further experiments were carried out to identify the mode of cell death induced by NDV AF 2240 and V4-UPM treatments. Previous studies have demonstrated the cytolytic potency of NDV on breast cancer cell lines (MCF-7 and MDA-231), brain tumor cell line (DBTRG.5MG and U87MG) and leukemia cell lines (HL-60 and CEM-SS) [18-22]. The present study showed that NDV strains did not induce cytolytic effect on normal mouse fibroblast (3T3) cells. This is in agreement with previous studies on the non cytolytic effects of NDV on 3T3 cells and also on other normal cells such as mouse spleen lymphocytes, peripheral blood mononuclear cells and cerebral cortex neurons (HCN-2) cells [14,21]. The tumor selective replication of NDV can be explained by that the normal (non-tumorigenic) cells exert the capability to block NDV infection by establishing an early antiviral state that prevents viral genome amplification. This state depends on the effect of type-I interferon (IFN) response and a functional IFN signaling cascade, which then lead to the stimulation of multiple defense mechanisms including a fast and prolong production of antiviral proteins. In addition, in tumor cells, the antiviral activity is defective at several points of the cascade so this in combination with defective translational control makes tumor cells highly susceptible to NDV infection [29]. Even recent progress in apoptosis research at the biochemical and molecular levels; morphological changes are still considered the gold standard for study apoptosis. During apoptosis, nucleus of the cell undergoes dramatic morphological changes including chromatin condensation, peripheral margination, nuclear shrinkage, and subsequent fragmentation. Budding and formation of apoptotic bodies can be observed visually by simple phase contrast light microscopy [30]. 


\begin{tabular}{|l|l|l|l|l|l|l|}
\hline \multicolumn{7}{|c|}{ AF2240 NDV Strains } \\
\hline \multicolumn{7}{|c|}{} \\
\hline $\begin{array}{l}\text { Caspases pro- } \\
\text { teins } \\
\text { levels (RLU) }\end{array}$ & $\begin{array}{l}\text { Caspases } \\
3 / 7\end{array}$ & $\begin{array}{l}\text { Caspases } \\
8\end{array}$ & $\begin{array}{l}\text { Caspases } \\
9\end{array}$ & $\begin{array}{l}\text { Caspases } \\
3 / 7\end{array}$ & $\begin{array}{l}\text { Caspases } \\
8\end{array}$ & $\begin{array}{l}\text { Caspases } \\
9\end{array}$ \\
\hline 3h un-treated & 830.0 & 860.0 & 5178.0 & 46.0 & 47.0 & 3995.0 \\
\hline 3h treated & 31879.5 & 3369.5 & 13426.0 & 195320.0 & 10130.0 & 36710.0 \\
\hline 6h un-treated & 995.0 & 997.5 & 5364.0 & 943.0 & 950.0 & 5586.0 \\
\hline 6h treated & 31107.5 & 3668.0 & 14113.0 & 165697.0 & 8421.0 & 38043.0 \\
\hline 24h un- treated & 4865.5 & 1577.0 & 8689.0 & 5061.5 & 1153.0 & 10999.0 \\
\hline 24h treated & 132156.0 & 16325.0 & 123991.0 & 92079.0 & 37206.0 & 205310.0 \\
\hline $\begin{array}{l}\text { Ratio of } \\
\text { increase from } \\
\text { 6h to 24h of } \\
\text { treated cells } \\
\text { (6h/24h) }\end{array}$ & $1: 4$ & $1: 4$ & $1: 9$ & $1: 2$ & $1: 4$ & $1: 5$ \\
\hline
\end{tabular}

Table 1: Levels of all three proteins caspases, caspase-3/7, caspase- 8 and caspase- 9 of HT-29 cells were determined by colorimetric assay after treatment with CD50 of NDV strains AF 2240 and V4-UPM separately at $3 \mathrm{~h}, 6 \mathrm{~h}$ and $24 \mathrm{~h}$ compared to un-treated cells.

$P$ values of caspases protein levels versus time exposure was statistically significant $(P \leq 0.05)$.

RLU: Relative Luminescence Units.

Fluorescent microscope using acridine orange and propidium iodide (AO/PI) staining used to distinguish viable, apoptotic and necrotic cells to determine the mode of cell death. The uptake of AO dye was seen in viable and apoptotic cells while necrotic cells were stained by PI [27]. In this study, confirmation of HT-29 cell apoptosis initiated by NDV AF 2240 and V4-UPM strains was done using the microscopic examination. Both phase contrast light and fluorescent microscopes were done which confirmed that NDV strains (AF 2240 and V4-UPM) in cell cultures induces cell death via the apoptotic pathway. The percentage of apoptotic cells proportionally increased with increasing time exposure while viable cells were significantly decreased with time of incubation. These results are similar to previous studies on leukemia cells (WEHI-3B), brain tumor cells (U-87MG and DBTRG.05MG), lung cancer cell line (A549) and Hela cell lines which observed increasing apoptosis cells compared to viable and necrosis cells after treated with NDV $[22,31-$ 33]. Apoptosis is a multistep, multi-pathway cell death program that is inherent in every cell of the body. The apoptotic pathways leading to cell death can generally be divided into two nonexclusive signaling cascades involving death receptors (extrinsic) pathway or mitochondria (intrinsic) pathway [34]. In both pathways of caspases, cysteine aspartyl-specific proteases (caspases) that cleave cellular substrates are stimulated, which leads to the morphological and biochemical changes characteristic of apoptosis pathway. Apoptosis initiated by death receptors; Fas-associating protein with a death domain (FADD) and following the activation of caspase-8, an initiator caspase [35]. Death at the mitochondrial level is started by disturbance of the mitochondrial membrane potential, and followed by release of cytochrome. Cytosolic cytochrome $\mathrm{c}$ triggers the formation of a multimeric Apaf-1/ cytochrome c/dATP/procaspase-9 protein complex termed the apoptosome and leads to the activation of caspase-9 [34].
To study the mechanism of apoptosis, we measured the protein levels of caspases 3/7, 8 and 9 in human colorectal adenocarcinoma (HT-29) cells after treatment with NDV strains AF 2240 and V4-UPM at different times. The results showed increased of three caspases proteins in HT-29 cells which treated with both NDV strains compared to non-treated cells. Interesting, the results herein showed higher increased caspase-9 level compared to caspase- 8 . This suggested that caspase-9 is essential for NDV induced apoptosis through (intrinsic) mitochondrial pathway of HT-29 cells. Activation of caspases-8 in this study may due to the result of the activation of caspases $3 / 7$ which has a position as a central executioner caspase in mammals [36]. Beginning with activation of caspase- 9 which then stimulates the caspase cascade through activation of caspases- 3 and -7 which then in turn activates caspases- 2 and -6 and then propagates activation of the downstream caspases- 8 and -10 [37].

The caspases assay results were further confirmed by the study the gene expression of Bax and Bcl-2. Caspases assay results were in agreement with previous studies that were conducted on Leukemia, Hela cell lines and A549 lung cancer cell lines [21,31,38]. In addition, a recent study by Ghriciet al. [39] confirmed that NDV AF 2240 induction of apoptosis in MCF-7 cells via mitochondrial pathway by using mitochondrial permeability transition pore opening assay. On the other hand, other study indicated that NDV is believed to promote cellular apoptosis via both pathways [40] while another study by Ravindra, etal. [41] which confirmed NDV induced apoptosis through extrinsic apoptotic pathway by increasing caspase-8. Apoptosis induction depends on the balance between $\mathrm{Bcl}-2$ and Bax gene expression [42,43]. Bcl-2 is an antiapoptotic protein and has the ability to block various apoptotic signals. On the other hand, Bax is another member of the Bcl-2 family but exerts a pro-apoptotic effect via the mitochondrial (intrinsic) 
pathway of apoptosis. In cancer cells, Bax overexpression increases apoptosis and lead to cell death [44-46]. One study mentioned that Bcl-2 might play a significant role in the development of colorectal carcinoma [47]. In this study Bax was upregulated in HT-29 cells that were treated with NDV strains (AF 2240 and V4-UPM) in contrast to down-regulation evident on untreated HT-29 cells. In contrast, Bcl-2 was up-regulated in non-treated cells and down-regulated in HT-29 cells that were treated with NDV strains (AF 2240 and V4-UPM). These results are suggesting that NDV induces apoptosis on human colorectal adenocarcinoma cells in vitro by affecting the expression of Bcl-2 family gene members and damaging the mitochondrial functions. Previous study by Molouki et al. [31] did not show any significant changes in the total levels of Bax and Bcl-2 proteins following infection of HeLa cells with NDV. However, another study by Ravindra et al.[41] observed that after infection of Vero cells with NDV, the Bax expression increased whereas Bcl-2 expression decreased. The differences between results could be strain and/or cell line-dependent and it could be concluded that NDV-induced apoptosis in these cell lines could follow different mechanisms.

From the data of the this study we can conclude that (i) HT29 cell apoptosis initiated by NDV AF 2240 and V4-UPM (ii) NDV AF 2240 and V4-UPM induced apoptosis of HT-29 through intrinsic (mitochondrial) pathway which determined by increased of caspase- 9 and higher expression of Bax compared to Bcl-2 and they are good anti-cancer agents of HT-29 human colorectal adenocarcinoma cells in vitro. The second part of the current study has been done in vivo which verified these results and will be published in the near future. However, further studies on various types of colon cancer cell lines with different doses of NDVstrains are needed to confirm these results.

\section{Acknowledgment}

We would like to thank "Doctor Jamal Mohammed Baathar" a specialists in Reproductive Health Independent Consultant, Sana'a, Yemen and "Doctor Myat Moe ThweAung" a lecturer in Medical Faculty, Universiti Sultan ZainalAbidin, Terengganu, Malaysia for their cooperation in statistical data analysis.

\section{References}

1) Russell SJ, Peng KW (2007) Viruses as anticancer drugs. Trends in Pharmacological Sciences 28: 326-333.

2) Meerani S, Yao Y (2010) Oncolytic Viruses in Cancer Therapy.European Journal of Scientific Research 40: 156 -171.

3) de Leeuw O, Peeters B (1999) Complete nucleotide sequence of Newcastle disease virus: Evidence for the existence of a new genus within the subfamily Paramyxovirinae. J.Gen. Virol 80: 131-136.

4) Nakaya TJ, Cros MS, Park Y, Nakaya Y, et al. (2001) Recombinant Newcastle disease virus as a vaccine vector. J. Virol 75: 11868-11873. 5) Alexander DJ, Elizabeth WA, Fuller CM (2012) The long view: a selective review of 40 years of Newcastle disease research. Avian Pathology 41: 329-335.

6) Nelson NJ (1999) Scientific interest in Newcastle disease virus is reviving. J Natl Cancer Inst 91: 1708-1710.

7) Schirrmacher V, Haas C, Bonifer R, Ahlert T, Gerhards R, Ertel C (1999) Human tumour cell modification by virus infection: an efficient and safe way to produce cancer vaccine with pleiotropic immune stimulatory properties when using Newcastle disease virus. Gene Ther6: 63-73.

8) PecoraAL Rizvi N, Cohen GI et al. (2002) Phase I trial of intravenous administration of PV701, an oncolytic virus, in patients with advanced solid cancers. J Clin Oncol 20: 2251-2266.

9) Omar AR, Ideris A, Ali AM, Othman F, Yusoff K, et al. (2003) An overview on the development of Newcastle disease virus as an anticancer therapy. Malays J Med Sci 10: 4-12.

10) Schirrmacher V, Bai L, Umansky V, Yu L, Xing Y, et al. (2000) Newcastle disease virus activates macrophages for anti-tumor activity. International Journal of Oncology 16: 363-373.

11) Washburn W, Weigand MA, Grosse-Wilde A, Janke M, Stahl H, et al. (2003) TNF-related apoptosis-inducing ligand mediates tumoricidal activity of human monocytes stimulated by Newcastle disease virus. J Immunol 170: 1814-1821.

12) Fábián CJ, Csatary CM, Szeberényi J, Csatary LK (2007) p53independent endoplasmic reticulum stress-mediated cytotoxicity of a Newcastle disease virus strain in tumor cell lines. Journal of Virology 81: 2817-2830.

13) Tan WS, Lau CH, Ng BK, Ibrahim AL, Yusoff K (1995) Nucleotide sequence of the haemagglutinin-neuraminidase (HN) gene of a Malaysian heat resistant viscerotropic-velogenic Newcastle disease virus. DNA Sequence 6: 47-50.

14) Othamn F, Ideris A, MotallebG, Eshak ZB (2010) Oncolytic effect of Newcastle disease virus AF 2240 strain on the MCF-7 breast cancer cell line. YakhtehMed J 12: 17-24.

15) Kusumaningtyas E, Tan WS, Zamrod Z, Eshaghi M, Yusoff K (2004) Existence of two forms of L protein of Newcastle disease virus isolates due to a compensatory mutation in Domain V. Arch Virol 149: 1859-1865.

16) Ideris A, Latif I, Spradbrow PB (1987) Development of food pellet Newcastle disease vaccine. Etching Press, Brisbane.

17) Ideris A, Ibrahim AL, Spradbrow PB (1990) Vaccination of chickens against Newcastle disease with a food pellet vaccine. Avian Pathology 19: 371-384.

18) Lorence RM, Richard KW, Katubig BB, Reyes HM, Phuangsab A (1994) Complete regression of human neuroblastoma xenografts in athymic mice after local Newcastle disease virus therapy. J.Natl. CancerInst 86: 1228-1233.

19) Freeman AI, Zakay-Rones Z, GomoriJM, Linetsky et al. (2006) Phase I/II trial of intravenous NDV-HUJ oncolytic virus in recurrent glioblastoma multiforme. MolTher 13: 221-228. 
20) Zulkifli MM, Ibrahim R, Ali AM, Ideris A, Jaafar H, et al. (2009) Newcastle diseases virus strain V4UPM displayed oncolytic ability against experimental human malignant glioma. Neurological Research 31: 3-10.

21) AlabsiMA, Abu Bakar SA, Ali R, Omar AR, et al. (2011) Effects of newcastle disease virus strains AF 2240 and V4-UPM on cytolysis and apoptosis of leukemia cell lines. International Journal of Molecular Sciences 12: 8645-8660.

22) Abu Bakar SA, Zawawi M, Ali AM, Ideris A (2012) Induction of Apoptosis by Newcastle Disease Virus Strains AF220 and V4-UPM in Human Promyelocytic Leukemia (HL60) and Human T-LymphoblasticLeukemia (CEM-SS) Cells. World Academy of Science, Engineering and Technology 64: 395-399.

23) Chambers P, Samson AC (1980) A new structural protein for Newcastle disease virus. J Gen Virol 50: 155-166.

24) Yusoff K, Tan WS, Lau CH, Ng BK, Ibrahim L (1996) Sequence of the haemagglutinin-neuraminidase gene of the Newcastle disease virus oral vaccine strain V4-UPM. Avian Pathol25: 837-844.

25) Alexander DJ (1988) Newcastle disease. In: Newcastle disease virus: an avian paramyxovirus. Kluwer Academic Publishers, Netherlands 11-22.

26) Mosmann T (1983) Rapid colorimetric assay for cellular growth and survival: application to proliferation and cytotoxicity assays. J Immunol Methods 65: 55-63.

27) Ali AM, Uma NT, Mohamed S M (2001) Induction of apoptosis in leukaemic cells by goniothalamin. JBiochemMolBiolBiophys 5 : 227-235.

28) Zhang X, Li B, Dong C, Ren R (2006) Apoptosis of human colon carcinoma HT-29 cells induced by ceramide. World J Gastroenterol 12: 3581-3584

29) Fournier P, Schirrmacher V (2013) Oncolytic Newcastle Disease Virus as Cutting Edge between Tumor and Host. Biology 2: 936-975.

30) Yigong S (2004) Caspase Activation: c Revisiting the Induced Proximity Model. Cell 117: 866-868.

31) Molouki A, Hsu YT, Jahanshiri F, Rosli R, Yusoff K (2010) Newcastle Disease Virus Infection Promotes Bax Redistribution to Mitochondria and Cell Death in HeLa Cells. Intervirology 53: 87-94.

32) Alabsi MA, Ali R, Ideris A, Omar AR, Bejo MH, et al. (2012) Anti-leukemic activity of Newcastle disease virus strains AF 2240 and V4-UPM in murine myelomonocytic leukemia in vivo. Leukemia Research 36: 634-645.

33) Fang FU, Zhao M, Yang Y, Tong G, Yang B, et al. (2011) Antiproliferative Effect of Newcastle Disease Virus Strain D90 on Human Lung Cancer Cell Line A549. Oncology Research 19: 323-333.

34) IgneyFH, Krammer PH (2002) Death and anti-death: tumour resistance to apoptosis. Nat. Rev. Cancer 2: 277-288.

35) Hu S, Vincenz C, Buller M, Dixit VM (1997) A novel family of viral death effector domain-containing molecules that inhibit both CD-95- and tumor necrosis factor receptor-1-induced apoptosis. J. Biol. Chem 272: 9621-9624.

36) SleeEA,Adrain C, Martin SJ (1999) Serial killers: Ordering caspase activation events in apoptosis.Cell Death Differ6: 1067-1074.

37) Woo M, Hakem R, Soengas MS, Duncan GS, Shahinian A, et al. (1998) Essential contribution of caspase 3/CPP32 toapoptosis and its associated nuclear changes. Genes Dev12: 806-819.

38) Meng S, Zhou Z, Chen F, Kong X, Liu H, et al. (2012) Newcastle disease virus induces apoptosis in cisplatin-resistant human lung adenocarcinoma A549 cells in vitro and in vivo. Cancer Lett 317: 56-64.
39) Ghric, M, El Zowalaty M, Omar AR, Ideris A (2013) Induction of apoptosis in MCF-7 cells by the hemagglutinin-neuraminidase glycoprotein of Newcastle disease virus Malaysian strain AF 2240. Oncology Reports 30: 1035-1044.

40) Elankumaran S, Rockermann D, Samal SK (2006) Newcastle disease virus exerts oncolysis by both intrinsic and extrinsic caspasedependent pathways of cell death. J Virol 80: 7522-7534.

41) Ravindra PV, Tiwari AK, Ratta B, Baisa MV, Chaturvedi U, et al. (2009) Time course of Newcastle disease virus-induced apoptotic pathways. Virus Research 144: 350-354.

42) Meterissian SH, Kontogiannea M, et al.(2001) Bcl-is a useful prognostic marker in Duke's B colon cancer. Ann. Surg. Oncol 8: 533-537.

43) Sakinah SA, Handayani ST, HawariahLP (2007) Zerumbone induced apoptosis in liver cancer cells via modulation of Bax/Bcl-2 ratio. Cancer Cell Int 7: 4-10.

44) Vaskivuo TE, Stenback F, TapanainenJS (2002) Apoptosis and apoptosis-related factors Bcl-2, Bax, tumor necrosis factoralpha, and NF-kappaB in human endometrial hyperplasia and carcinoma. Cancer 95: 1463-1471.

45) Yamaguchi H, Bhalla K, Wang H (2003) Bax plays a pivotal role in thapsigargin-induced apoptosis of human colon cancer HCT116 cells by controlling Smac/Diablo and Omi/HtrA2 release from mitochondria. Cancer Res 63: 1483- 1489.

46) Kobayashi T, Sawa H, Morikawa J, Zhang W, Shiku H (2000) Bax induction activates apoptotic cascade via mitochondria cytochrome c release and Bax of the expression enhances apoptosis induced by chemotherapeutic agents in DLD-1 colon cancer cells. J Cancer Res 91: 264-1268.

47) Sheehan KM, O’Donovan DG, Fitzmaurice G, O'Grady A, O'Donoghue DP (2003) Prognostic relevance of Fas ligand in human colorectal cancer. Eur J GastroenterolHepatol 15: 375-380.

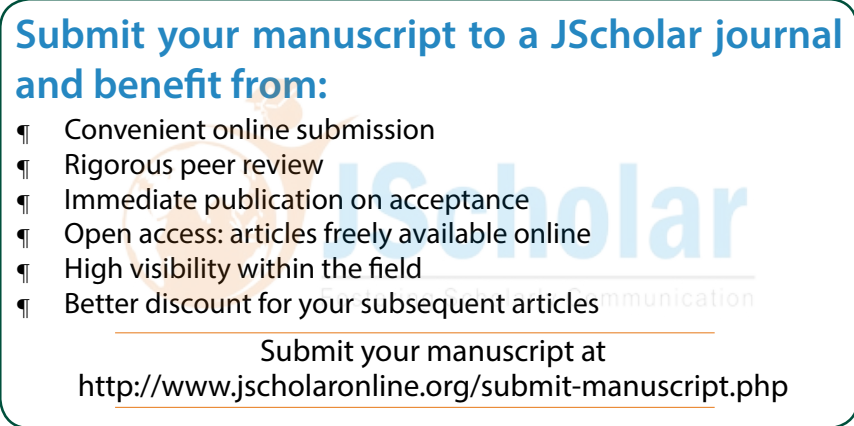

